\title{
Сведок времена: Библиотека женског стваралаштва у Истанбулу
}

\author{
Мирјана Маринковић \\ Универзитет у Београду \\ Филолошки факултет - Катедра за оријенталистику, Београд \\ mirjana.marinkovic65@gmail.com
}

\begin{abstract}
Сажетак
У свету постоји више библиотека посвећених стваралаштву жена. Међу њима су најпознатије Феминистичка библиотека (The Women`s Library) при Лондонској школи за економске и политичке науке (The London School of Economics and Political Science), основана 1926, Феминистичка библиотека у Глазгову (Glasgow Women`s Library), основана 1991, Феминистичка библиотека (Feminist Library) у Лондону, основана 1975. те Библиотека женског стваралаштва и информациони центар у Истанбулу (Kadınlar Eserleri Kütüphanesi ve Bilgi Merkezi Vakfі), која постоји од 1990. године. За разлику од побројаних библиотека у Великој Британији које претежно прикупљају писану грађу од значаја за историју борбе за друштвена и политичка права жена од краја 19. века, Библиотека женског стваралаштва у Истанбулу осмишљена је као институција окренута целокупном стваралаштву које потиче од жена, али и оном које је посвећено женама и бави се тзв. женским темама и питањима. Ова библиотека је у исти мах и информациони центар са низом посебних фондова, публикација и пројеката која привлачи пажњу активизмом и ентузијазмом те организацијом низа научних, стручних и других манифестација из области своје делатности.
\end{abstract}

Кључне речи: Kadınlar Eserleri Kütüphanesi ve Bilgi Merkezi Vakfı (Библиотека женског стваралаштва у Истанбулу), библиотека, информациони центар, женско стваралаштво, Истанбул, Турска

Увод

Библиотека женског стваралаштва и информациони центар у Истанбулу постоји од 8. марта 1990. године и ради као фондација (вакуф). То је једина установа те врсте у Турској. Налази се у веома лепом старом здању на Фанару, делу Истанбула који је познат по седишту Васељенске патријаршије. Саму зграду уредила је и рестаурирала Скупштина града Истанбула. Отварање ове библиотеке за кориснике 14. априла 1990. године може да се сматра важним датумом у турском феминистичком покрету који се развио осамдесетих година прошлог века и почео да преиспитује мушке и женске идентитете и улоге, а „нарочито постојеће друштвене родне обрасце“. ${ }^{1}$ Тзв. „женско питање“ актуализовано је из најмање два разлога: први је већи утицај турске левице након војног удара 12. септембра 1980. године, а други јачање радикалних исламистичких снага које су добиле крила под утицајем Исламске револуције у Ирану 1979. године. Као противтежа десничарским и исламистичким идеологијама, у Турској се осамдесетих година оснажује демократски грађански покрет са „сликом жене“ у западњачко-кемалистичком, тј. републиканском духу. Радикални феминизам који се шездесетих година појавио на Западу утицао је у великој мери на турске жене из средњих и виших грађанских слојева. ${ }^{2}$ Отуда се 1987. године у Турској покреће Феминисииички иасойис, а 1988. часопис

\footnotetext{
1 Fatmagül Berktay, Türkiye'de Kadın Hareketi: Bir Tarihçe, preuzeto 27. 4. 2020, http://www.hazardernegi.org/turkiyede-kadin-hareketi -bir-tarihce/.

2 H. Kaçmazoğlu, „Türkiye'de Kadın Sorunu Üzerine Sosyolojik Bir Yaklaşım”. Atatürk Üniversitesi Sosyal Bilimler Dergisi 0 (2013): 75-77.
} 


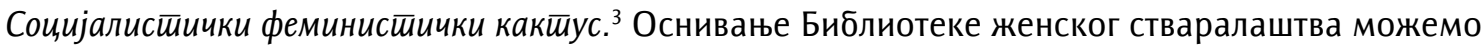
схватити као једну од етапа у институционализацији женског покрета.

\section{Континуитет институције вакуфа}

Вакуфи или задужбине јесу највидљивија обележја турске културе, позната од најстаријих, преисламских времена. Попут древних Сумераца, Вавилонаца и Хетита, постоје сведочанства да су и Турци средње Азије подизали многе задужбине у славу Буде. Упркос оскудности података, сматра се да су задужбинарске повеље Турака Ујгура у источном Туркестану настале чак у 13. и 12. веку пре н.е. ${ }^{4}$

Ова традиција настављена је и развијана у пуној светлости историје, у време Селџука и Турака Османлија који су од почетка 10. века ступили у исламски цивилизацијски круг. Процењује се да вакуфско наслеђе из селџучких и османских времена на територији Турске данас броји око 52.000 објеката о којима се стара Генерална управа вакуфа Републике Турске. ${ }^{5} \mathrm{Ba}-$ куф је термин који подразумева препуштање неке имовине која би заувек требало да служи јавном интересу под условима и по вољи вакифа, тј. особе која том имовином располаже и која је оставља на добробит друштва. ${ }^{6}$ Мотив за завештање имовине био је чињење доброг дела за спас душе на оном свету. Вакуфи су биле институције од посебног значаја, јер се највећи део социјалног, економског, образовног и културног живота одвијао у оквиру њих. Услуге пружања социјалне помоћи, унапређења живота, здравства, образовања које су данас у надлежности модерне државе, традиционално су биле брига вакуфа који су функционисали у готово свим сферама живота - економском, просветном, религиозном, здравственом, спортском, цивилном и војном. ${ }^{7}$ Вакуфе су остављали сви који су за то били у могућности - од султана и султанија, државних и верских великодостојника до обичног света који се руководио идеалима доброчинства и служења заједници. „Није, међутим, све било либерално као што изгледа“, пише Годфри Гудвин, наводећи вакуф султаније Хурем, вољене жене султана Сулејмана Величанственог. Она је, уз султанову дозволу, употребила државни новац за народну кухињу и џамију у Јерусалиму као личну задужбину, „чиме се на корумпиран начин исказивала лична благонаклоност за добробит принцезине душе." Чак су 182 старца била издржавана у том вакуфу, а велика кухиња два пута дневно делила је хлеб и чорбу сиромашнима. ${ }^{8}$

Урбани, али не само урбани живот у Османској империји није могуће замислити без институције вакуфа као најубедљивијег израза солидарности и међусобног помагања становништва. Готово све непрофитне установе, јавна добра и објекти, попут џамија, медреса, библиотека, болница, сиротишта, водовода, каравансараја, настали су као део ове традиције која је очувана и у данашњој Републици Турској у облику различитих фондација, легата, задужбина успостављених приватном иницијативом и улагањем приватног капитала, попут Библиотеке женског стваралаштва у Истанбулу.

\section{Оснивање Библиотеке женског стваралаштва}

Ову библиотеку су основале истакнуте турске интелектуалке Асли Даваз (Aslı Davaz), Фусун Акатли (Füsun Akatlı), Фусун Ертуг Јараш (Füsun Ertuğ Yaraş), Жале Бајсал (Jale Baysal)

\footnotetext{
3 Kaçmazoğlu, „Türkiye'de Kadın Sorunu Üzerine Sosyolojik Bir Yaklaşım”: 77.

${ }^{4}$ Mehmet Bayartan, "Osmanlı Sehirlerinde Vakıflar", Osmanlı Bilimi Araștırmaları X-1 (2008): 158.

${ }^{5}$ T. C. Vakiflar Genel Müdürlüğü, "Tarihte Vakıflar", preuzeto 26. 4. 2020, https://www.vgm.gov.tr/kurumsal/tarihce/tarihte-vakiflar.

${ }^{6}$ Mehmet Zeki Pakalın, Osmanlı Tarih Deyimleri ve Terimleri Sözlüğ, 3 (istanbul: Milli Eğitim Basımevi, 1983), 577-580.

7 Bayartan, "Osmanlı Şehirlerinde Vakıflar": 171

${ }^{8}$ Godfri Gudvin, Privatni svet osmanskih žena (Beograd: Geopoetika, 2015), 109.
} 
и Ширин Текели (Şirin Tekeli). Увидом у њихове богате биографије закључује се да је реч о изузетним духовима и активним јавним радницама у Турској, које су се поред својих каријера посветиле прикупљању и сређивању књишке и друге грађе од значаја за историју женског покрета и женског стварања у целини.

Асли Даваз је до 2019. године била чланица или председница Управног одбора Библиотеке у више мандата. Школована је у Француској, где је завршила француски језик. Дугогодишњи је преводилац са овог језика. Једно време усавршавала се у Енглеској, где је истраживала рад и организацију више јавних библиотека. У циљу отварања библиотеке у Турској у чијем фокусу је жена, знања је стицала у Паризу у Библиотеци Маргерит Диран (Bibliothèque Marguerite Durand) и библиотекама Фосет (The Fawcett Library) и Феминистичкој библиотеци (Feminist Library) у Лондону. Учествовала је на више научних скупова и конгреса из области библиотекарства и архивистике. Активно је доприносила повезивању Библиотеке женског стваралаштва у Истанбулу са сличним институцијама у свету. Иницирала је формирање више значајних збирки Библиотеке о којима ће ниже бити речи. Важи за експерта из области феминоцентричне архивистике.

Фусун Акатли је дипломирала филозофију, а докторирала из области књижевне критике. Радила је као универзитетски професор, драматург, књижевни критичар, есејиста. Посебно је заслужна за организацију дискусија и окупљање савремених књижевница под сводовима Библиотеке женског стваралаштва. Написала је низ књига, есеја и књижевних огледа.

Фусун (Јараш) Ертуг је позната као стручњак у области етноботанике и етноархеологије. Докторирала је у Вашингтону на Универзитету Ст. Луис 1991. године. Поред активног научноистраживачког рада и учешћа у више пројеката, Фусун (Јараш) Ертуг је посебно ангажована у пословима обезбеђивања приватних архива и сређивања визуелног материјала Библиотеке.

Жале Бајсал (1926-2009) је била истакнуто име у области библиотекарства у Турској. Написала је на десетине студија и више књига, међу којима се посебно истиче Увоg у исшорију књиіе и библиошеке (1991). Бавила се и књижевним радом. Супруг јој је био познати турски писац Тарик Бугра.

Ширин Текели (1944-2017) је од свих оснивача Библиотеке женског стваралаштва у Истанбулу била најнепосредније укључена у феминистички покрет у Турској. На вест о њеној смрти, угледни дневник Хуријеш̄ написао је да је Ширин Текели „једно од првих имена на које се помисли када је реч о женском покрету и феминистичким студијама у Турској“. ${ }^{9}$ Образовала се у Француској, где је започела студије права, и Швајцарској, где је завршила политичке науке. Докторирала је у Истанбулу са тезом „Жене и друштвено-политички живот“. Након војног удара 1980. године и Закона о високом образовању 1981, напустила је универзитет у знак протеста. Узела је активног учешћа у низу кампања, попут Марша солидарности против насиља (1987), реформи Грађанског законика, захтева за примену Споразума о спречавању сваке врсте дискриминације жена (1985). Ширин Текели је на позив Удружења писаца (YAZKO - Yazarlar Kooperatifi) постала члан групе преводилаца којима је поверено превођење феминистичке литературе на турски језик. Превела је више од двадесет књига о феминизму и демократији, објавила више књига, студија и чланака у међународним академским публикацијама, а нарочито је заслужна за увођење специфичне социолошке и феминистичке терминологије у турски језик. ${ }^{10}$

Сврха и циљ оснивања ове установе је „боље познавање прошлости жена, систематично пружање података истраживачима и чување писане документације која настаје у наше доба

\footnotetext{
9 "Kadın hareketi yasta... Şirin Tekeli hayatını kaybetti", Hürriyet, Haber Giriş: 14. 6. 2017, preuzeto 26. 4. 2020, https://www.hurriyet.com.tr/gundem/kadin-hareketi-yasta-sirin-tekeli-hayatini-kaybetti-40489126.

${ }^{10}$ Kadın Eserleri Kütüphanesi ve Bilgi Merkezi Vakfı: Kadın Merkezli Bir Kütüphane ve Arşiv, Kurucular Kurulu, preuzeto 26. 4. 2020, http://kadineserleri.org/vakif-organlari/.
} 
за будуће генерације." ${ }^{\prime 11}$ Збирке ове библиотеке обухватају разноврсну грађу коју су створиле жене, или која се односи на жене од времена Османске империје до данашњих дана.

\section{Осврт на историју женског питања код Турака}

Жена постаје видљива у турском друштву у епохи Танзимата (1839-1876) у којој државни врх Османске империје започиње низ политичких и административних реформи које за циљ имају модернизацију и европеизацију друштва.Тадашњи напредни интелектуалци - Ибрахим Шинаси (İbrahim Şinasi), Намик Кемал (Namık Kemal) и други, у књижевним делима и дебатама покрећу и тзв. „женско питање“ као питање које зорно показује степен еманципације целог друштва. У драми Песниково вениање (1859) писац и новинар Ибрахим Шинаси обрађује тему венчања између младих људи који у брак улазе, а да једно друго претходно нису ни видели ни упознали. Сличну тему разматра Намик Кемал у драмском делу Јаgно gē̄e. Ахмет Мидхат (Ahmet Midhat), један од најплоднијих турских књижевника 19. века, снажно се залаже за еманципацију жена, једнак приступ образовању и равноправност са мушкарцима. ${ }^{12}$ Занимљиво је да се положајем жене баве реформатори мушкарци, што Дениз Кандијоти тумачи као „моћно средство да изразе сопствено немирење са друштвеним конвенцијама које сматрају нарочито будаластим и архаичним". ${ }^{13}$

Године 1842. почиње са радом Медицинска школа у којој су се, под надзором европских инструкторки, школовале бабице. Женске средње школе (женске руштије) основане су 1858, Женска занатска школа 1869, да би Учитељска школа била отворена 1870. године. До тада жене су образовање стицале приватно у својим домовима, а и то је била привилегија оних из вишег друштвеног сталежа. ${ }^{14}$

Снажнију подршку образовању и друштвеном ангажовању жена донео је младотурски покрет (1908-1918), који се описује као „ера патриотског феминизма“. ${ }^{15}$ Назив младотурске партије био је Комитет уједињења и прогреса. Њихова идеологија базирана је на парламентаризму, турском (не османском ${ }^{16}$ ) патриотизму, стварању снажне турско-муслиманске средње класе. Успели су да тзв. „младотурском револуцијом“ 1908. поврате на снагу Устав из 1876, који је суспендовао султан Абдулхамид II, распустивши парламент 1878. због рата са Русијом (1877-1878). Младотурски политичари су увиђали да је за напредак друштва од кључног значаја еманципација жене. Они су „у целини, желели да виде османску жену како се развија по моделу западњачке жене захваљујући напретку и образовању. $У$ том циљу, развила се женска литература и покренута гласила посебно посвећена женама у којима су се јављале родно освешћене турске интелектуалке. ${ }^{17}$ Најпознатији и најдуговечнији женски часопис Hanımlara Mahsus Gazete (Лисши за gаме) имао је јасно формулисану уређивачку политику која је требало да афирмише образовану, честиту жену, добру мајку, добру супругу и добру муслиманку. ${ }^{18}$ Између 1908. и 1916. године основано је „не мање од туцета женских удружења, која су се

\footnotetext{
11 Kadın Eserleri Kütüphanesi ve Bilgi Merkezi Vakfı: Kadın Merkezli Bir Kütüphane ve Arşiv, preuzeto 8. 4. 2020, http://kadineserleri.org/hakkimizda/.

12 Mirjana Marinković, Nova turska književnost (Beograd: Filološki fakultet, 2017): 28-43.

${ }^{13}$ Deniz Kandiyoti, "End of Empire: Islam, Nationalistm and Women in Turkey", u Women, Islam and the State (London: Macmillan, 1991), 26

14 Isto, 28; Исто је важило и за мушкарце. Изузимајући школовање у верским школама, уобичајено је било да се стручно знање и вештине стичу од старијих кроз видове неформалног образовања. На пример, чиновнички посао се учио од старијег колеге и таква пракса је била врло распрострањена.

15 Kandiyoti, "End of Empire: Islam, Nationalistm and Women in Turkey", 28.

${ }^{16}$ Османизам као идеја стварања наднације која би окупила под истим кишобраном разнолике етничке и религијске структуре доживео је крах.

17 Исӣорија Османскої иарсӥва, прир. Робер Мантран (Београд: Clio, 2002), 706-707.

18 Zehra Öztürk, "Hanımlara Mahsus Gazete. Osmanlı Döneminde En Uzun Ömürlü Kadın Dergisi", Türkiye Diyanet Vakfı islam Ansiklopedisi, preuzeto 28. 4. 2020, https://islamansiklopedisi.org.tr/hanimlara-mahsus-gazete.
} 
кретала од примарно филантропских организација до оних која су се отвореније ангажовала у борби за женска права“. ${ }^{19}$ Међу њима је и Друштво за уздизање жена, које је основала књижевница Халиде Едип Адивар (Halide Edip Adıvar, турска Вирџинија Вулф) 1908. године. Оно је било повезано са британским сифражетским покретом и захтевало од својих чланица да познају енглески језик. ${ }^{20}$ Идеолог младотурског покрета, утемељивач идеологије турског национализма, социолог и књижевник Зија Гокалп (Ziya Gökalp) залагао се за повратак исконским вредностима туркизма, истичући „демократичност и феминизам као два главна принципа древног турског живота“. Сходно томе, младотурци су имали идеал моногамне „националне породице“ као новог породичног модела насупрот старој патријархалној османској породици. ${ }^{21}$

Ипак, није све било тако једноставно. Сам младотурски покрет није био идејно јединствен и монолитан. Читаво друштво трпело је притиске и споља и изнутра, а подвојеност између традиционалног и модерног никада није престајала. Ако се свестраније анализира јавни дискурс и турска књижевност стварана у Османској империји у 19 веку, али и у Републици Турској током највећег дела 20. века, стиче се утисак сталног дуализма и преиспитивања - Запад или Исток, ново или старо, европске или османске (турске) вредности. Куриозитет је да се младотурски Комитет уједињења и прогреса усред Првог светског рата (1917) бавио дужином женске сукње. Енвер-паша, један од његових вођа, уклонио је једног од својих команданата на Дарданелима зато што су му се кћери сунчале на Босфору!²2

Први балкански и Први светски рат допринели су већој друштвеној видљивости и ангажованости турских жена које су се истицале као болничарке, раднице и подршка ратницима на фронту. Највећи допринос, међутим, турске жене су дале током Рата за независност, под рудководством Мустафе Кемала (Ататурка) 1919-1923. Улога анадолских сељанки глорификована је као никада до тада у уметности и јавној речи. Незихе Мухитин (Nezihe Muhittin), председница тадашње организације Национална странка жена, истицала је права које су жене извојевале учешћем у рату: „Турска жена би требало да дели поновно рођење своје земље. Ми, турске жене, морамо да у друштвеном и политичком животу нађемо место које заслужујемо; то право нам дају наш самопрегор и служба у рату за ослобођење". ${ }^{23}$

Подршка женској еманципацији, међутим, није долазила од религиозних и конзервативних кругова које је Мустафа Кемал настојао да уједини са борцима за слободу. У сваком случају, нема сумње да је женско питање, као и у епохи Танзимата, било добра платформа за његову одлучну борбу за ликвидацију теократских реликата османског друштва и културе, „борбу у којој су мушки протагонисти ангажовали једни друге док су женеу целини и на опште изненађење остале пасивни посматрачи. “24

Стање се тешко и споро мењало и у републиканској Турској, будући да је патријархалност, некада заснована на религији, сада почивала на идеји нације, а „нова жена“ се сматрала најбољим симболом повезаности те нације, како је објаснила Фатмагул Берктај (Fatmagül Berktay). Тек су се после 1980. године, захваљујући женском активизму и потреби усклађивања са међународним споразумима, стекли услови да се у Грађански законик унесу измене у правцу изједначавања жене са мушкарцем и укидања дискриминације у сваком погледу. Тај процес окончан је тек крајем 2001. године. ${ }^{25}$

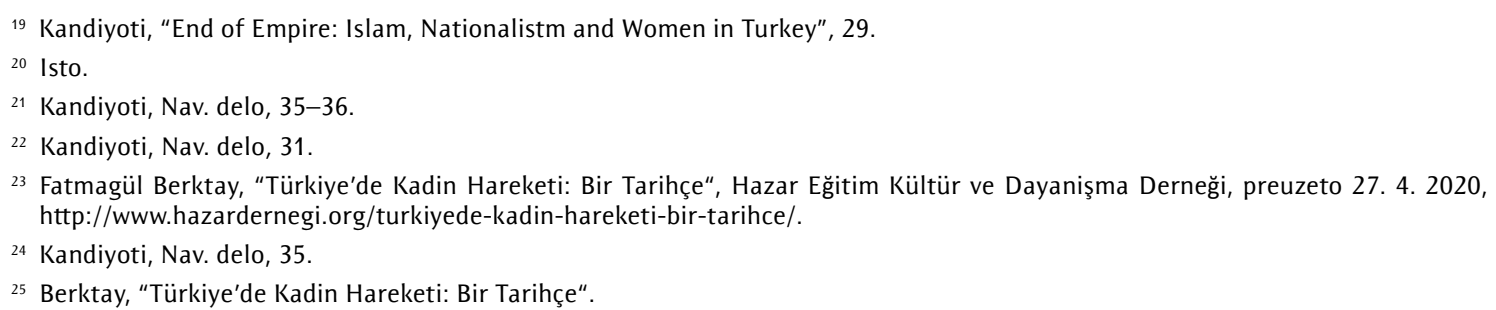




\section{Жена и књига у турској традицији}

Жена и књигау турској традицији, можда значајно више него у другим, показатељ су друштвене еманципације. Појава учитељице хануме у светлу проевропских модернизаторских иницијатива код Османлија у 19. веку најзначајнији је тренутак у стварању новог друштвеног миљеа. „Повећање броја женске деце и подизање степена образовања до нивоа гимназије на крају XIX века обезбедили су појаву нове професионалне групе. Учитељице хануме... У историји Турске улазак жене у живот слободног рада догодио се на пољу образовања пре него у индустрији. То је један од разлога за снажну позицију жене у бирократији у данашњој Турској“, пише Илбер Ортајли (İlber Ortaylı) и у напомени примећује да су у последњем раздобљу Османске империје на високим школама школоване студенткиње, за разлику од европских и северноамеричких универзитета, који нису примали студенткиње, или им нису дозвољавали излазак на дипломске испите. ${ }^{26}$

Мајка султана Абдулмеџида (Abdülmecid) (1839-1861), Безимиалем (Bezmialem), пореклом Грузијка, остала је упамћена не само по блиставој интелигенцији и култури, које је пренела на сина, већ и као велика добротворка коју је народ обожавао. Верује се да је лично опремила библиотеку дворца Долмабахче великим бројем дела француске књижевности на којима су остале сачуване белешке више генерација читалаца. Такође, заслужна је за отварање школе за девојчице са „добро опремљеном библиотеком“. ${ }^{27}$

То не значи да се на учене жене обавезно гледало благонаклоно. Фрапантан је податак да је Фатми Алије (Fatma Aliye, 1862-1936), првој турској романсијерки и једној од најученијих турских жена у 19. веку, којој су књиге и подучавање били једини истински свет, супруг у првим годинама брака забрањивао да чита, пише и говори француски језик!28

Погрешно је мишљење о турским женама као пасивним и скрајнутим бићима. То посебно важи за мајку као стуб породице. Немачки протестантски свештеник Соломон Швајгер запажао је, током путовања по Турској у 16 . веку, да се „Турци који ужасавају цели свет прибојавају својих жена". ${ }^{29}$

Ауторитет жене и мајке по свој прилици потиче из давних времена и није се изгубио ни након примања ислама. Као што су многи обичаји, веровања и системи мишљења (шаманистички култови, на пример, обожавање духовних вођа који су у исламској ери попримили лик дервишких старешина и др.) остали дубоко урезани у свест и након преласка на ислам, тако је и моћ мајке остала неокрњена. У неким областима Турске, на пример, мајка која би на свет донела мушко дете имала би, што би постајала старија, све већу моћ у породици у односу на мужа. ${ }^{30}$ Славни еп турског племена Огуза Књиї Деgе Коркуш̄а приказује жене као равноправне по храбрости са мушкарцима. Мајкама се у истом епу указује највеће поштовање. ${ }^{31}$ То потврђује и однос султана према својим мајкама - валиде султанијама. ${ }^{32}$ Сачувани су описи раскошних процесија када би се у двор усељавала нова валиде султанија након што би њен син ступио на престо. ${ }^{33}$ Није непознат често негативан утицај султанија мајки и султанских жена на политички живот у империји. У жељи да избегне уплитање своје мајке у доношење политичких одлука, султан Абдулхамид II (1876-1909) јој је саопштио: „Имаћете сва права и овлашћења валиде султаније на двору. Али, нарочито вас молим да се стриктно чувате да на

\footnotetext{
26 Илбер Ортајли, Најgужи век Имйерије (Београд: Српска књижевна задруга, 2004), 211.

27 Gudvin, Privatni svet osmanskih žena, 163.

${ }^{28}$ Güven Taneri Uluköse, Fatma Aliye. Bir Biyografi (istanbul: Cinius Yayınları, 2013), 40.

29 ilber Ortaylı, Osmanlı Düşünce Dünyası ve Tarihyazımı (İstanbul: Türkiye İş Bankası Kültür Yayınları, 2010), 79.

30 Kaçmazoğlu „„Türkiye'de Kadın Sorunu Üzerine Sosyolojik Bir Yaklaşım”: 86

${ }_{31}$ Mirjana Marinković, Stara turska književnost (Beograd: Filološki fakultet, 2012), 187

32 Валиде султанија је мајка султана на престолу.

33 Gudvin, Nav. delo, 139.
} 
себе преузимате уплитање у државне послове и узимате овога или онога у заштиту и указујете на оне жељне чинова и намештења." 34

\section{Фонд библиотеке}

Најстарије публикације и грађа похрањена у Библиотеци женског стваралаштва у Истанбулу потиче с краја 19. века и састоји се од 48 приватних архива, више од 14.000 књига, преко 469 периодичних публикација и више од 8012 јединица названих Efemera. Сав материјал је каталогизован и разврстан у више збирки које се непрестано допуњују. Како је ово уједно и амбициозно осмишљен документациони центар, у њему се чувају не само писани извори, већ и богат аудио и видео-материјал, „тродимензионални материјал“, архивска грађа - женске новине и часописи, приватни архиви жена, породична документација, писма, дневници, документација женских удружења и организација. У библиотеци се чувају аутобиографије и биографије жена, филмови, постери, фотографије, уметничка дела, записани наративни извори.

3бирке Библиотеке женског стваралаштва су следеће:

1. Збирка приватних архива у којој су рукописне белешке, писма, документа, преписка, фотографије, као и приватни предмети знаменитих и заслужних жена попут њихових писаћих машина, брошева, плакета, оловака и другог. Међу њима су Суреја Агаоглу (Süreyya Ağaоğlu, 1903-1989), прва жена адвокат у Турској, ${ }^{35}$ песникиња Халиде Нусрет Зорлутуна (Halide Nusret Zorlutuna, 1901-1984), сценаристикиња и преводилац Неџиле Тевфик (Necile Tevfik, 1911-1964), романсијерке Букет Узунер (Buket Uzuner), Инџи Арал (İnci Aral), Пинар Кур (Pınar Kür), научница и политичка активисткиња Фатмагул Берктај (Fatmagül Berktay) и приватне архиве појединих оснивачица Библиотеке женског стваралаштва (Жале Бајсал, Фусун Ертуг) и других. Поред ових личних архива, Библиотека чува и архиве појединих женских удружења као што су Федерација сороптимистичких клубова Турске, Удружења универзитетски образованих жена Турске, Удружења медицинских сестара Турске и других.

2. Збирка књига која обухвата дела књижевница, истраживачке радове о жени у Турској, женским покретима у Турској и свету. У моменту оснивања, Библиотека је располагала са 100 књига, да би тај број данас премашио 14.000 наслова. Овај фонд се састоји од књижевних дела турских књижевница из османске и републиканске ере (на османском и латиничном писму), као и научна дела и студије из области женског питања.

3. Збирка периодике која је подељена на два дела; први део обухвата листове и часописе пре 1928, када је у Турској уведено латинично писмо, и после 1928. године. Публикације на арабици, старом писму, посебно се обрађују и прилагођавају савременом језику за потребе корисника који не владају арабицом и османским турским језиком. Сачињене су и детаљане библиографије појединих публикација о којима ће ниже бити речи. Прелаз на латинично писмо 1928. године, заједно са покретом језичког пуризма тридесетих година, представља највећи догађај у култури Турака у 20. веку. Захваљујући Мустафи Кемалу Ататурку остварен је сан реформатора 19. века који су увиђали да старо арапско писмо не одговара фонетском систему турског језика и да је сметња за описмењавање и напредак нације. У експресном року извршена је реформа писма, док

\footnotetext{
${ }^{34}$ Süleyman Kocabaş, Sultan II. Abdülhamid. Şahsiyeti ve Politikası (i̇stanbul: Vatan Yayınları, 1995), 149.

35 Остало је забележено да је као приправница одлазила на ручак у један ресторан у Анкари у коме су по обичају ручавали само мушкарци. Њено незадовољство тиме дошло је, преко оца Ахмета Агаоглуа, директора Управе за штампу, до Ататурка, кога је тако нешто веома наљутило те је позвао неколико народних посланика и рекао им да сутрадан ручају у том ресторану. Ово је пример начина на који су понекад морале да буду уклањане преживеле навике и обичаји у републиканској Typcкој.-Erdem Yılmaz, "Türkiye'nin ilk KadınAvukatı Süreyya Ağaoğlu'nun Atatürk'le Anısı Kadın Hakları Açısından BirDers Niteliğinde!", Oneido, preuzeto 27.4.2020, https://onedio.com/haber/turkiye-nin-ilk-kadin-avukati-sureyya-agaoglu-nun-ataturk-le-kadin-haklari-acisindan-dersniteligindeki-anisi-8606620̈.
} 
се реформа језика одвијала тако што су избачене многе речи и конструкције позајмљене из арапског и персијског језика које су надомештене изворним турским речима или неологизмима. ${ }^{36}$

4. 3бирка женских организација чува документацију и грађу о више од 700 различитих женских институција и организација. Најстарија је Организација анадолских сестара (Bacıyân-ı Rûm Teşkilâtı) коју је у 13. веку основала Фатма Баџи (Fatma Bacı). Ty je похрањена и документација већ поменутих удружења с краја 19. и почетка 20. века, Иницијативе жена за мир, Центра за истраживање женских питања Универзитета у Истанбулу, Фондације Женска солидарност и других.

5. Збирка Efemera настала је прикупљањем грађе настале у пригодним приликама или посебним поводима, као што су водичи, упутства, програми манифестација, поруке. На веб-страници Библиотеке налазе се занимљиве фотографије овог материјала, попут „Водича за исхрану у трудноћи“, „16 поносних мајки се описменило“, „Симпозијум о проблемима и решењима жена са хендикепом“, „Жена - жени, здравље жене“ и друге. Овај материјал се прибавља праћењем одговарајућих догађаја и откупом.

6. Збирка названа „Жене писци“ садржи 11.300 докумената који су саставни део биографских досијеа књижевница. У њој се могу наћи приватне фотографије, нацрти, рукописи дела, белешке и друга документација које су оне поклониле овој задужбини. Вредна је документација за 22 књижевнице из предрепубликанског (Фатме Алије, Нигјар, Незихе Мухитин) и републиканског доба (Адалет Агаоглу, Ајше Кулин, Инџи Арал).

7. Збирка „Жене уметнице“ похрањује најразноврснија уметничка дела чији су ствараоци жене - слике, графике, скулптуре, фотографије, карикатуре, као и податке о, у овом тренутку, 2078 уметница, међу којима су портретисткиња Михри Мушфик (Mihri Müşfik, 1886-1954), прва апстрактна уметница у Турској Фахруниса Зејд (Fahrünnisa Zeyd, 1901-1991), керамичарка Фуреја Корал (Füreya Koral, 1910-1997), вајарка Зерин Болукбаши (Zerrin Bölükbaşı, 1919-2010).

8. Збирку визуелног материјала чине фотографије познатих жена - прве жене пилота у Турској Сабихе Гокчен (Sabiha Gökçеn), девојака учесница за први избор за мис Турске, оснивачица женских удружења у османско доба, женских ношњи, породичне и личне фотографије, фотографије разних женских кампања, митинга и маршева у републиканско доба, разгледнице, слајдови, видео-записи, албуми и слично.

9. Аудио-збирка - у њој су сачувани аудио-записи предавања, интервјуа, јавних читања и других активности које је Библиотека организовала. Садржи 202 касете и 61 компакт-диск снимљеног материјала. Већина материјала снимљена је током деведесетих година прошлог века.

10. 3бирка постера и плаката насталих активношћу разних женских удружења, политичких партија, организација цивилног друштва, као и постера које је сама Библиотека израдила за својих тридесет година постојања. У овој збирци су плакати холивдуских филмова 1950-1960. године, плакати са изложби жена уметница, политичких организација и женских удружења, разних манифестација, симпозијума, семинара, прослава. Укупно се чува 596 постера и плаката.

11. Збирка уметничких дела се састоји од 117 експоната - уметничких слика у различитим техникама, карикатура, скулптура, литографија, сериграфија, гравира. Ова збирка је настала као резултат изложби уметничких дела које је Библиотека организовала у периоду од 1990. до 1998. године, а након којих су ауторке по један примерак поклањале овој установи. Због недостатка простора, овакве изложбе се више не организују од 1998. године.

${ }^{36}$ Marinković, Nova turska književnost, 109-115. 
12. Збирка новинских исечака. Обухвата новинске написе од 1990. године, тј. од оснивања Библиотеке. Садржај је подељен у 17 тема - породица, мајчинство, запослене жене, држава и политика, вера и жена, образовање, етничке групе, миграције, активности за женска права, табуи о женама, феминизам, хумор, жена у уметности, рад са друштвеном сврхом, насиље, међународне установе и делатности. Збирка је корисна за истраживаче женске стварности и питања на дневном нивоу, о чему најбоље сведочи штампа.

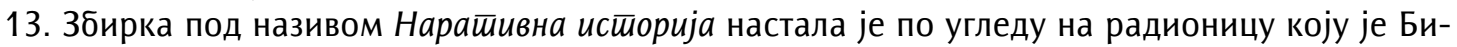
блиотека женског стваралаштва организовала 1991. године, уз учешће Патрише Милер Кинг из Библиотеке Шлезинџер из САД, на тему „Шта је наративна историја“. Након тога покренуте су серије разговора са одређеним групама жена - на пример, са женама различитих професија рођеним пре проглашења Републике Турске 1923, женама народним посланицама и другим. Аудио-записи тих разговора су дигитализовани.

14. Збирку ретких дела чини 313 књига, било да су их написале жене или су написане о женама, а до којих се дошло преко аукција или продаваца старих књига. Истраживачима су на располагању стара издања Дивана (збирке песама) Лејле Саз, романа Ханgан и Севије Талий Халиде Едип Адивар, романа Разіоовори (Muhadarat) Фатме Алије, дела Муслиманка Мухамеда Ферида Веџдија, Наше иесникиюе Ахмеда Мухтара и мноштво других наслова. У овој збирци су и дипломе женских школа 19. века.

15. Збирка магистарских и докторских теза које за тему имају неко од питања везаних за различите аспекте живота жена - друштвене, образовне, медицинске, књижевне, политичке и друге.

16. Збирка чланака обухвата 7220 радова на турском и страним језицима. Међу њима су текстови у академским часописима, издањима женских организација, поглавља у књигама. Наслови ових радова су изузетно занимљиви: „Како су се пре 150 година венчавали на истанбулским свадбама“, „Арапске жене преиспитују свој статус", „Француска књижевница Жорж Санд“, „Полигамија у Истанбулу између 1885. и 1926. године“, "Феминизам у османској штампи 1899. године“, "Јерменка у османском друштву 19. века“. ${ }^{37}$

Библиотека женског стваралаштва у Истанбулу има и разрађену издавачку делатност. У првом плану је израда библиографија као посебно значајних публикација за научноистраживачки рад. До сада су урађене следеће библиографије:

- İstanbul Kütüphanelerindeki Eski Harfli Türkçe Kadın Dergileri Bibliyografyası (1869-1927) Библиографија женских часописа на турском језику и на старом писму у истанбулским библиотекама (1869-1927);

- Hanımlar Âlemi'nden Rozaya Kadın Sürel iYayınları Bibliyografyası (1928-1996) - Библиографија женских периодичних публикација од Свеша gама до Розе (1928-1996); ${ }^{38}$

- Kadın Yazıları: Kadınların Edebiyat Ürünleri, Kadınlar Üzerine Yazılanlar ve Tezler Bibliyografyası (1955-1990) - Женско писмо: библиографија књижевих дела жена, текстова написаних о женама и теза (1955-1990);

- Kadın Konulu Kitaplar Bibliyografyası (1729-2002) - Библиографија књига написаних на тему жене од увођења штампе у Османском царству 1729. до 2002. године. Ова библиографија је темељни водич за истраживаче, будући да су издања систематизована у више тематских целина - опште теме, историјски развој, право, религија, образовање, здравље и психологија, сексуалност, брак - брачни односи, феминизам, појам насиља и насиље према жени и другим.

\footnotetext{
37 Kadın Eserleri Kütüphanesi ve Bilgi Merkezi Vakfı:Kadın Merkezli Bir Kütüphane ve Arşiv, Makale Koleksiyonu, preuzeto 27.4.2020, http://kadineserleri.org/koleksiyonlar/makale-koleksiyonu/.

${ }^{38}$ Roza је први курдски феминистички часопис који је почео да излази 8. марта 1996. године. За четири године, колико је излазио, објављено је 17 бројева.
} 
Нашу пажњу посебно привлачи едиција под називом Cећање на жене (Kadınların Belleği Dizisi Yayınları). У овкиру тог веома опсежног и захтевног пројекта, који је подржала Амбасада Финске у Турској, објављени су, на латиничном писму, турски женски часописи који су излазили пре преласка на латиницу. На тај начин је оживљено сећање на турске жене с краја 19. и почетка 20. века, њихову свакодневицу, преокупације, укус, навике, стандард и целокупну друштвену атмосферу у којој су живеле, а све са намером да они који не владају османским турским језиком могу да се служе том обимном и занимљивом грађом. Од почетка пројекта 2010. до данас објављене су две едиције под истим називом. Прва обухвата следеће посебне књиге:

1. Kadın Yolu/Türk Kadın Yyolu (1925-1927) -Пуш жене/Пуш ширске жене (1925-1927);

2. Hanımlara Mahsus Gazete - Seçki (1895-1908) - Лисш за gаме - Нзбор (1895-1908);

3. Kadınlar Dünyası 1.-50./51.-100 (1913-1921) - Свеш жена 1-50/51-100 (1913-1921);

4. Yeni Harflerle Kadın: II. Meşrutiyet Döneminde Bir Jön Türk Dergisi (1908-1909) - Жена на но-

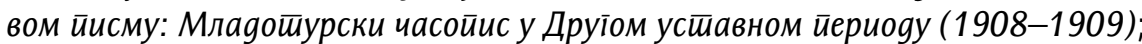

5. Türk Kadını (1918-1919) - Турска жена (1918-1919);

6. Genç Kadın (1919 Ocak-Mayıs) - Млаgа жена (1919 јануар-мај);

7. Aile (1880) ve Hanım (1921) - Пороguи, (1880) и Госйођа (1921). ${ }^{39}$

Другу едицију чине два издања:

1. Yeni Harflerle Bilgi Yurdulşığı (1917-1918) / Osmanlı ve Erken Cumhuriyet Kadın Dergileri: Talepler, Engeller, Mücadele - Cilt 1 -Свешилосш gомовине знања (1917-1918) на новом иисму /Женски часойиси османскої и ранореӣубликанскої gоба: захйеви, ирейреке, борба- том 1.

2. Yeni Harflerle İnsaniyet (1882-1883); Kadınlık Hayatı (1913); Erkekler Dünyası (1914); Ev Hocası (1923); Firuze (1924) / Osmanlı ve Erken Cumhuriyet Kadın Dergileri: Talepler, Engeller,

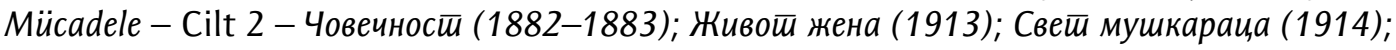
Домаћин (1923); Тиркиз (1924) на новом йисму/ Женски иасойиси османскої и ранорейубликанскої gоба: захйеви, иреиреке, борба - том $2 .^{40}$

Свака посебна књига садржи обимне и темељно написане предговоре који су врло важни теоријски оквири за сагледавање не само улоге конкретног часописа у времену и друштву, већ и укупних прилика у којима су живеле и радиле турске жене. Они су још значајнији имајући у виду да су родне студије релативно нове не само у Турској, већ и у читавом свету.

Поред ових издања, Библиотека је објавила три каталога приватних архива прве жене адвоката у Турској Суреје Агаоглу, вајарке Зерин Болукбаши и турске књижевнице, новинарке и активисткиње за женска права Неџиле Тевфик. ${ }^{41}$ Пажње је вредан и подухват превођења књиге Еиropean Women `s Thesaurus на турски језик под насловом Kadın Konulu Kavramlar Dizini, који садржи стандардизоване појмове који се јављају у литератури посвећеној феминистичким темама.

За тридесет година постојања, Библиотека је организовала више симпозијума и објавила четири зборника радова. Први доноси радове са међународног скупа феминистичких библиотека

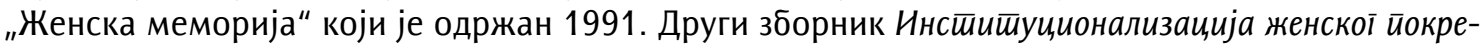
$\bar{u} a-\bar{u}$ илике и ризиии настао је као плод истоименог конгреса одржаног 1991. године у Бону, а који је, трудом посленика и пријатеља Библиотеке женског стваралаштва у Истанбулу преведен на турски језик. Трећи, Проблем извора у насшанку женске меморије објављен је 2009. године, када је и одржан научни скуп на исту тему. Четврти зборник доноси радове са међународног научног скупа који је Библиотека организовала 2014. године у сарадњи са Универзитетом

\footnotetext{
${ }^{39}$ Kadın Eserleri Kütüphanesi ve Bilgi Merkezi Vakfı: Kadın Merkezli Bir Kütüphane ve Arşiv, Kadınların Belleği Dizisi Yayınları, preuzeto 8. 4. 2020, http://kadineserleri.org/kadinlari-bellegi-dizisi/.

${ }^{40}$ Kadın Eserleri Kütüphanesi ve Bilgi Merkezi Vakfı: Kadın Merkezli Bir Kütüphane ve Arşiv, Kadınların Belleği Dizisi - 2 Yayınları, preuzeto 8. 4. 2020, http://kadineserleri.org/kadinlarin-bellegi-dizisi-2-yayinlari/.

${ }^{41}$ Kadın Eserleri Kütüphanesi ve Bilgi Merkezi Vakfı: Kadın Merkezli Bir Kütüphane ve Arşiv,ÖzelArşivlerKatalogDizisiYayınları, preuzeto 8. 4. 2020, http://kadineserleri.org/ozel-arsivler-katalog-dizisi/.
} 


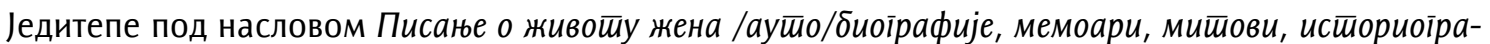
фuја. ${ }^{42}$ Уједно, то је и највећи научни скуп ове библиотеке са преко 200 учесника из целог света.

\section{Закључак}

Библиотека женског стваралаштва у Истанбулу уистину је „радионица“ и „инспирација“43 која организује низ запажених манифестација - књижевних вечери, дискусија, предавања, пројекција, изложби и сличних садржаја. ${ }^{44}$ Библиотека има веома добро уређен веб-сајт и својим присуством у јавности игра све активнију улогу у афирмацији женског стваралаштва и чувању од заборава разноврсног материјала од значаја за живот жене.

Велики је број пројеката које је Библиотека покренула и реализовала уз подршку истакнутих научних и културних институција и појединаца, све са циљем да се потенцијалним корисницима учини доступном богата књижевна и архивска грађа. Од посебног значаја је дигитализација прикупљеног материјала која ће у догледно време олакшати рад и, верујемо, надахнути многе истраживаче историје турске жене, али и турског женског стваралаштва које је веома занимљиво и вредно.

Међу бројним личностима које су донацијама подржале ову установу у време њеног оснивања су и нека знаменита имена савремене Турске, попут чувене лекарке Туркан Сајлан (Türkan Saylan), књижевница Лејле Ербил (Leyla Erbil), Пинар Кур (Pınar Kür), Ерендиз Атасу (Erendiz Atasü) и многих других. Библиотека женског стваралаштва у Истанбулу свакако симболизује однос „жене и књиге, жене и писања, жене и корпуса знања и традиције 45 и то јој даје истакнуто место у савременој турској култури. Она исцртава портрет турске жене у времену и простору.

Библиотека женског стваралаштва је са својим све богатијим фондом својеврстан сведок историје и положаја турске жене, њеног стваралачког духа, пратилац њених успона и падова, борбе и надања, противречности у којима се и данас налази растрзана између још увек дубоко укорењене патријархалности и извојеване слободе. На основу информативног веб-сајта Библиотеке очито је да ова институција игра врло видну улогу у културном и јавном животу Истанбула и Турске. Последња забележена активност било је отварање изложбе плаката (12-27. марта) који приказују последњих четрдесет година борбе турских жена против патријархалног наслеђа која је приређена у Републичкој уметничкој галерији на Таксиму. ${ }^{46}$

\section{Литература и извори:}

1. Bayartan, Mehmet. "Osmanlı Şehirlerinde Vakıflar", Osmanlı Bilimi Araştırmaları X-1 (2008): 157-175.

2. Berktay, Fatmagül. "Türkiye'de Kadin Hareketi: Bir Tarihçe". Hazar Eğitim Kültür ve Dayanişma Derneği. Preuzeto 27. 4. 2020. http://www.hazardernegi.org/turkiyede-kadin-hareketi-bir-tarihce/.

\footnotetext{
${ }^{42}$ Kadın Eserleri Kütüphanesi ve Bilgi Merkezi Vakfı: Kadın Merkezli Bir Kütüphane ve Arşiv, Sempozyum Bildiri Kitapları, preuzeto 8. 4. 2020, http://kadineserleri.org/sempozyum-bildiri-kitaplari/.

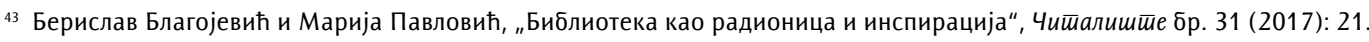

${ }^{44}$ Kadın Eserleri Kütüphanesi ve Bilgi Merkezi Vakfı: Kadın Merkezli Bir Kütüphane ve Arşiv, Web-Sitesi-Etkinlikler-1990-2016-03-2020, preuzeto 8. 4. 2020, http://kadineserleri.org/wp-content/uploads/2020/03/Web-Sitesi-Etkinlikler-1990-2016-03-2020.pdf; Kadın Eserleri Kütüphanesi ve Bilgi Merkezi Vakfı:Kadın Merkezli Bir Kütüphane ve Arşiv, Etkinlikler, preuzeto 8. 4. 2020, http://kadineserleri.org/category/etkinlikler/.

45 Владислава Гордић Петковић, „Библиотека у сопственој соби: ауторке, јунакиње и књиге од Вирџиније Вулф до данас“, читалишеше бр. 31 (2017): 31

${ }^{46}$ Kadın Eserleri Kütüphanesi ve Bilgi Merkezi Vakfı: Kadın Merkezli Bir Kütüphane ve Arşiv, Etkinlikler, Preuzeto 27. 4. 2020, http:// kadineserleri.org/category/etkinlikler/.
} 
3. Blagojević Berislav i Marija Pavlović. „Biblioteka kao radionica i inspiracija“. Čitalište: naučni časopis za teoriju i praksu bibliotekarstva br. 31 (2017): 21-26.

4. Gudvin, Godfri. Privatni svet osmanskih žena. Beograd: Geopoetika, 2015.

5. Gordić Petković, Vladislava. „Biblioteka u sopstvenoj sobi: autorke, junakinje i knjige od Virdžinije Vulf do danas". Čitalište: naučni časopis za teoriju i praksu bibliotekarstva br. 31 (2017): 27-32.

6. Istorija Osmanskog carstva, prir. Rober Mantran. Beograd: Clio, 2002.

7. Kaçmazoğlu, H. „Türkiye'de Kadın Sorunu Üzerine Sosyolojik Bir Yaklaşım”. Atatürk Üniversitesi Sosyal Bilimler Dergisi 0 (2013): 75-90.

8. Kadın Eserleri Kütüphanesi ve Bilgi Merkezi Vakfı: Kadın Merkezli Bir Kütüphane ve Arşiv. Preuzeto 8. 4. 2020. http://kadineserleri.org/hakkimizda/.

9. Kadın Eserleri Kütüphanesi ve Bilgi Merkezi Vakfı: Kadın Merkezli Bir Kütüphane ve Arşiv. Etkinlikler. Preuzeto 8. 4. 2020. http://kadineserleri.org/category/etkinlikler/.

10. Kadın Eserleri Kütüphanesi ve Bilgi Merkezi Vakfı: Kadın Merkezli Bir Kütüphane ve Arşiv. Kadınların Belleği Dizisi Yayınları. Preuzeto 8. 4. 2020. http://kadineserleri.org/kadinlari-bellegi-dizisi/.

11. Kadın Eserleri Kütüphanesi ve Bilgi Merkezi Vakfı: Kadın Merkezli Bir Kütüphane ve Arşiv. Kadınların Belleği Dizisi - 2 Yayınları. Preuzeto 8. 4. 2020. http://kadineserleri.org/ kadinlarin-bellegi-dizisi-2-yayinlari/.

12. Kadın Eserleri Kütüphanesi ve Bilgi Merkezi Vakfı: Kadın Merkezli Bir Kütüphane ve Arşiv. Kurucular Kurulu. Preuzeto 26. 4.2020.http://kadineserleri.org/vakif-organlari/.

13. Kadın Eserleri Kütüphanesi ve Bilgi Merkezi Vakfı: Kadın Merkezli Bir Kütüphane ve Arşiv. Makale Koleksiyonu. Preuzeto 27. 4. 2020. http://kadineserleri.org/koleksiyonlar/makale-koleksiyonu/.

14. Kadın Eserleri Kütüphanesi ve Bilgi Merkezi Vakfı: Kadın Merkezli Bir Kütüphane ve Arşiv. ÖzelArşivlerKatalogDizisiYayınları. Preuzeto 8. 4. 2020. http://kadineserleri.org/ ozel-arsivler-katalog-dizisi/.

15. Kadın Eserleri Kütüphanesi ve Bilgi Merkezi Vakfı: Kadın Merkezli Bir Kütüphane ve Arşiv. Sempozyum Bildiri Kitapları. Preuzeto 8. 4. 2020. http://kadineserleri.org/sempozyum-bildiri-kitaplari/.

16. Kadın Eserleri Kütüphanesi ve Bilgi Merkezi Vakfı: Kadın Merkezli Bir Kütüphane ve Arşiv. Web-Sitesi-Etkinlikler-1990-2016-03-2020. Preuzeto 8. 4. 2020. http://kadineserleri.org/wp-content/uploads/2020/03/Web-Sitesi-Etkinlikler-1990-2016-03-2020.pdf.

17. "Kadın hareketi yasta... Şirin Tekeli hayatını kaybetti". Hürriyet, Haber Giriş: 14. 6. 2017, preuzeto 26. 4. 2020. https://www.hurriyet.com.tr/gundem/ kadin-hareketi-yasta-sirin-tekeli-hayatini-kaybetti-40489126.

18. Kandiyoti, Deniz. "End of Empire: Islam, Nationalistm and Women in Turkey". U Women, Islam and the State. London: Macmillan, 1991.

19. Kocabaş, Süleyman. Sultan II. Abdülhamid. Şahsiyeti ve Politikası. İstanbul: Vatan Yayınları, 1995.

20. Marinković, Mirjana. Stara turska književnost. Beograd: Filološki fakultet, 2012.

21. Marinković, Mirjana. Nova turska književnost. Beograd: Filološki fakultet, 2017.

22. Ortajli, Ilber. Najduži vek imperije. Beograd: Srpska književna zadruga, 2004.

23. Ortaylı, İlber. Osmanlı Düşünce Dünyası ve Tarihyazımı. İstanbul: Türkiye İş Bankası Kültür Yayınları, 2010.

24. Öztürk, Zehra. "Hanımlara Mahsus Gazete. Osmanlı Döneminde En Uzun Ömürlü Kadın Dergisi". Türkiye Diyanet Vakfı İslam Ansiklopedisi. Preuzeto 28. 4. 2020. https://islamansiklopedisi.org.tr/ hanimlara-mahsus-gazete.

25. Pakalın, Mehmed Zeki. Osmanlı Tarih Deyimleri ve Terimleri Sözlüğü,3. İstanbul: Milli Eğitim Basımevi, 1983.

26. T. C. Vakiflar Genel Müdürlüğü. "Tarihte Vakıflar". Preuzeto 26. 4. 2020. https://www.vgm.gov.tr/ kurumsal/tarihce/tarihte-vakiflar.

27. Uluköse, Güven Taneri. Fatma Aliye. Bir Biyografi. İstanbul: Cinius Yayınları, 2013.

28. Yılmaz, Erdem. "Türkiye'nin İlk Kadın Avukatı Süreyya Ağaoğlu'nun Atatürk'le Anısı Kadın Hakları Açısından BirDers Niteliğinde!". Oneido. Preuzeto 27. 4. 2020. https://onedio.com/haber/turkiye-nin-ilkkadin-avukati-sureyya-agaoglu-nun-ataturk-le-kadin-haklari-acisindan-ders-niteligindeki-anisi-860662ö. 


\title{
Witness of Time: Women`s Library in Istanbul
}

\begin{abstract}
Summary
The Women's Library and Information Centre Foundation (WLICF) in Istanbul is a non-profit institution founded in 1990. It is a library of women's artistic and literary works, but it also keeps collections of periodicals, manuscripts, personal documents, audio and video material, rare works and other sources related to women's life and reality from the Ottoman times until today. The library owns more than 14.000 books, 48 private archives, more than 469 periodicals, a lot of artistic works, paintings, sculptures made by women etc. This institution organized several symposiums and workshops, a lot of public conferences and readings, and prepared dozens of round tables and exhibitions. Among these activities, the Library published several books and works on a variety of projects concerning digitalization of old periodicals and sources.

This paper presents the library itself, but also gives an overview of two phenomena that allow an essential understanding of the specifics of its activities in modern Turkey. One is the institution of waqf, the most convincing expression of solidarity and the mutual assistance of the population without which it is impossible to imagine urban life in the Ottoman Empire. In that way - as a result of private initiative and investment of private capital, the Women's Library in Istanbul was established. The second phenomenon covered is the phenomenon of women, their position and role in society and especially their attitude towards books. The Women's Library, with its increasingly rich collection, is a kind of witness to the history and position of Turkish women and their creative spirit, a companion of their ups and downs, struggles and hopes, contradictions in which they are still torn between still deeply rooted traditional patriarchal values and the freedom they have won.
\end{abstract}

Keywords: Women's Library and Information Centre Foundation (WLICF), library, information center, women's works, Istanbul, Turkey

\section{Zamanın Şahidi: Kadın Eserleri Kütüphanesi ve Bilgi Merkezi Vakfı}

Özet

Kadın Eserleri Kütüphanesi ve Bilgi Merkezi Vakfı 1990 yılında i̇stanbul'da kurulmuştur. Kadınların sanatsal ve edebi eserlerini saklayan bir kütüphane olup ancak aynı zamanda Osmanlı döneminden günümüze kadar kadının yaşamı ve gerçekliği ile ilgili süreli yayınlar, el yazmaları, kişisel belgeler, ses ve video materyalleri, nadir eserler ve diğer kaynakların koleksiyonlarını saklamaktadir. Kütüphanede 14.000'den fazla kitap, 48 özel arşiv, 469'dan fazla sürel yayın, bir çok sanatsal eser, tablo, kadın tarafından yapılmış heykeller vb. bulunmaktadır. Bu kurum kadın merkezli birkaç sempozyum ve atölye çalışması düzenledi, çok sayıda kamu konferansı ve kitap tanııımı, yuvarlak masa ve sergiler hazırladı. Bu faaliyetler arasında Kütüphane, eski süreli yayınların ve kaynakların dijitalleştirilmesi ile ilgili çeşitli projeler üzerinde çeşitli kitaplar ve eserler yayınladı. Bu makalede kütüphanenin kendisi incelenmektedir, fakat aynı zamanda günümüz Türkiye'sinde faaliyetlerinin özellikleri hakkında temel bir kavrayışa yol açan iki olguya genel bir bakış verilmektedir. Birincisi, Osmanlı İmparatorluğu'nda kentsel yaşamı hayal etmeyi imkansız kılan ve nüfusun dayanışma ve yardımlaşmasının en ikna edici ifadesi olan vakıf kurumudur. Kadın Eserleri Kütüphanesi de özel girişim ve özel sermayenin yatırımı ile modern bir vakıf olarak kuruldu. Ele alınan ikinci olgu, kadın fenomeni, kadının toplumdaki konumu ve rolü ve özellikle kitapla olan ilişkisidir

Kadın Eserleri Kütüphanesi, günden güne zenginleşen fonları ile, Türk kadının tarihine ve konumuna, yaratıcı ruhuna, onun iniş ve çıkışlarına, mücadeleler ve umutlarına, bugün hala köklü ataerkillik ve kazanılan özgürlük arasında çelişkili durumda bulunmasına özel bir șekilde tanıklık etmektedir.

Anahtar kelimeler: Kadın Eserleri Kütüphanesi ve Bilgi Merkezi Vakfı, kütüphane, bilgi merkezi, kadın eserleri, Istanbul, Türkiye 


\section{(@) $\Theta \Theta($}

Сведок времена: Библиотека женског стваралаштва у Истанбулу by Мирјана Маринковић is licensed under a Creative Commons Attribution-NonCommercial-NoDerivatives 4.0 International License. 